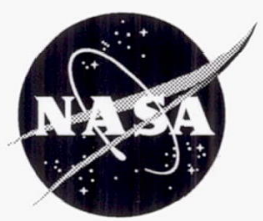

Non-Invasive, Quantitative, and Remote Detection of Early Radiation Cataracts for Applications in Bio-Astronautics and Bio-Informatics

Rafat R. Ansari

National Center for Microgravity Research, Cleveland, Ohio

Frank J. Giblin

Eye Research Institute, Oakland University, Rochester, Michigan

James F. King

Dynacs Engineering Company, Inc., Brook Park, Ohio 
Since its founding, NASA has been dedicated to the advancement of aeronautics and space science. The NASA Scientific and Technical Information (STI) Program Office plays a key part in helping NASA maintain this important role.

The NASA STI Program Office is operated by Langley Research Center, the Lead Center for NASA's scientific and technical information. The NASA STI Program Office provides access to the NASA STI Database, the largest collection of aeronautical and space science STI in the world. The Program Office is also NASA's institutional mechanism for disseminating the results of its research and development activities. These results are published by NASA in the NASA STI Report Series, which includes the following report types:

- TECHNICAL PUBLICATION. Reports of completed research or a major significant phase of research that present the results of NASA programs and include extensive data or theoretical analysis. Includes compilations of significant scientific and technical data and information deemed to be of continuing reference value. NASA's counterpart of peerreviewed formal professional papers but has less stringent limitations on manuscript length and extent of graphic presentations.

- TECHNICAL MEMORANDUM. Scientific and technical findings that are preliminary or of specialized interest, e.g., quick release reports, working papers, and bibliographies that contain minimal annotation. Does not contain extensive analysis.

- CONTRACTOR REPORT. Scientific and technical findings by NASA-sponsored contractors and grantees.
- CONFERENCE PUBLICATION. Collected papers from scientific and technical conferences, symposia, seminars, or other meetings sponsored or cosponsored by NASA.

- SPECIAl PUBLICATION. Scientific, technical, or historical information from NASA programs, projects, and missions, often concerned with subjects having substantial public interest.

- TECHNICAL TRANSLATION. Englishlanguage translations of foreign scientific and technical material pertinent to NASA's mission.

Specialized services that complement the STI Program Office's diverse offerings include creating custom thesauri, building customized data bases, organizing and publishing research results... even providing videos.

For more information about the NASA STI Program Office, see the following:

- Access the NASA STI Program Home Page at http://www.sti.nasa.gov

- E-mail your question via the Internet to help@sti.nasa.gov

- Fax your question to the NASA Access Help Desk at 301-621-0134

- Telephone the NASA Access Help Desk at 301-621-0390

- Write to: NASA Access Help Desk NASA Center for AeroSpace Information 7121 Standard Drive Hanover, MD 21076 
Non-Invasive, Quantitative, and Remote Detection of Early Radiation Cataracts for Applications in Bio-Astronautics and Bio-Informatics

Rafat R. Ansari

National Center for Microgravity Research, Cleveland, Ohio

Frank J. Giblin

Eye Research Institute, Oakland University, Rochester, Michigan

James F. King

Dynacs Engineering Company, Inc., Brook Park, Ohio

Prepared for the

Space Technology and Applications International Forum sponsored by the American Institute of Physics

Albuquerque, New Mexico, February 11-14, 2001

Prepared under Cooperative Agreement NCC3-544

National Aeronautics and

Space Administration

Glenn Research Center 


\section{Acknowledgments}

Authors are thankful to ophthalmologist Dr. L.-R. Lin of Oakland University in Michigan for examining the animals regularly. Thanks are also due to summer intern Anup Misra for his computing skills in collating an enormous amount of data. Rafat R. Ansari thankfully acknowledges the support provided by NASA's Office of Life and Microgravity Sciences and Applications under a NASA-NIH interagency agreement.

Rafat R. Ansari also wishes to thank Dr. Manuel B. Datiles III, of NEI/NIH for helpful discussions and a gift of IOL's for irradiation experiments. Frank J. Giblin acknowledges National Institutes of Health grants EY-02027 and EY-05230 (Core Center Grant).

Available from

NASA Center for Aerospace Information

7121 Standard Drive

Hanover, MD 21076
National Technical Information Service 5285 Port Royal Road Springfield, VA 22100 


\title{
Non-Invasive, Quantitative, and Remote Detection of Early Radiation Cataracts for Applications in Bio-Astronautics and Bio-Informatics
}

\author{
Rafat R. Ansari \\ National Center for Microgravity Research on Fluids and Combustion \\ 21000 Brookpark Road, Mail Stop 333-1 \\ Cleveland, Ohio 44135 \\ Phone: 216-433-5008, Fax: 216-977-7138 \\ E-mail: ratatransari@grc.nasa.gov \\ Frank J. Giblin \\ Eye Research Institute \\ Oakland University \\ Rochester, Michigan 48309 \\ Phone: 248-370-2395, Fax: 248-370-2006 \\ E-mail: giblin@oakland.edu \\ James F. King \\ Dynacs Engineering Company, Inc. \\ 2001 Aerospace Parkway \\ Brook Park, Ohio 44142
}

\begin{abstract}
Human exploration of Mars may be a possibility in the next twenty years. Maintaining good vision is an essential aspect of achieving a successful mission. Continuous radiation exposure is a risk factor for radiation-induced cataracts in astronauts. A compact device based on the technique of dynamic light scattering (DLS) is designed for monitoring an astronaut's ocular health during long-duration space travel. Preliminary data on the simulated effects of ionizing radiation exposure to the ocular tissues of non-human animals and results on the sensitivity of DLS over established clinical procedures in investigating cataracts are presented. This capability of early diagnosis, unmatched by any other clinical technique in use today, may enable prompt initiation of preventive/curative therapy. An inter-net web based system integrating photon correlation data and controlling the hardware to monitor cataract development in vivo at a remote site in real time (tele-ophthalmology) is currently being developed. Cataract studies on-board the International Space Station (ISS) will be helpful in designing better protective radiation shields for future space vehicles and space suits.
\end{abstract}

\section{INTRODUCTION}

Innovations in new optical technologies, higher computing powers, and development of compact smart systems are paving the way to make science fiction become reality. The dream of sending humans to Mars and bring them back to Earth safely seems possible in the next twenty years. A round-trip to Mars is expected to take about three years. From the point of view of human health and safety the travel to Mars could be very challenging. First, the human body has to endure long-duration microgravity conditions and secondly, it must cope with the problem of exposure to hazardous cosmic radiation. Outer Space is filled with ionizing and UV radiation. Several components of these cosmic radiations are found on earth or can be produced in laboratories. These include alpha particles (helium nucleus), beta particles (electrons), high-energy photons known as gamma radiation and X-rays, and neutrons (emitted during a nuclear explosion). The crew is expected to be safe inside a space-craft since it is made of shielding materials that protect them from ionizing radiation. But still the exposure to radiation during the Mars expedition is a real concern. The so-called "normal" radiation levels around a space ship may not be so normal. Travel through the solar disturbances and Van Allen radiation belts outside the earth's atmosphere (400 to 40,000 miles) are examples of this. Recently, the Chandra satellite telescope surprisingly observed extraordinary levels ( 1 billion times higher than that of Jupiter) of X-ray radiation from a LP944-20 Brown dwarf (Rutledge 2000). Astronauts in earlier space missions more than 40 years ago frequently reported visible light sensations. It was later found that these sensations were caused by cosmic charged particles passing through the retina. The effect of high- 
energy accelerated particles on the crystalline lens of laboratory animals has been discussed by Fedorenko (1995). In this paper we are concerned with the development of radiation cataract in astronauts and cosmonauts. Cataract is the gradual opacification of the transparent eye lens. Here on Earth, at the present time, there is no medical cure for cataract, except for surgical removal of the lens and replacement with an intra-ocular lens (IOL) implant. Within six months to a year after a cataract surgery, secondary cataracts are formed but they can be easily removed with a YAG laser. Surgeries in a space environment or on distant planets during the expedition phase may not be a viable option. And, who knows, even the IOL implants commonly made of plastic material may be affected by the ionizing or UV radiation. Presently, we are conducting experiments by irradiating IOL's with X-rays and gamma rays. Here on Earth, at the present rate, cataract may become an epidemic in the next twenty years. Therefore it would be very helpful to Mars-bound astronauts and millions of cataract sufferers here on Earth if we could detect cataract at an early stage of its development and stop or reverse its progression by non-surgical means. The new technology described below is able to detect cataracts very early.

\section{STATE-OF-THE-ART IN CATARACT EVALUATION}

Cataract is the major cause of blindness worldwide. At the present time clinical methods of classifying cataracts are based mainly upon visual acuity (Snellen charts) and photographic means (slit-lamps). The inside of the eye is illuminated either directly or indirectly (retro-illumination) by a slit from an incandescent source of light. These approaches, however, are subjective since they cannot be accurately quantified. Further, they do not have the ability to capture a growing cataract in its incipient stage. Therefore by the time a cataract is diagnosed by these methodologies it is too late to alter its course non-invasively or medically. The technique of dynamic light scattering (DLS) holds promise in detecting cataract much earlier non-invasively and quantitatively than the photographic techniques currently in use. Tanaka and Benedek (1975) first proposed the use of DLS in studying cataractogenesis. Recently new and compact fiber-optic probes developed for microgravity fluids experiments (Ansari, 1996, 1998), were applied to ophthalmology (Ansari, 2000, Sebag 1999).

DLS is a very sensitive tool for monitoring diffusive motion of particles suspended in transparent (e.g., water) dispersions. The particles diffuse due to the Brownian motion (thermal energy) of fluid molecules. The fluid molecules therefore constantly bombard upon the particles and impart momentum. Light of a uniform intensity from a laser entering a sample interacts with the suspended particles. This interaction gives rise to scattering. The scattered light collected temporally at a photo-detector fluctuates in intensity. These fluctuations depend upon the diffusive or transport properties and hence on the size of the suspended particles. A time correlation function (TCF) is constructed by correlating these light intensity fluctuations. The slope of a TCF yields a diffusion coefficient which can yield a size or size distribution. The details can be seen in Chu's book (Chu 1974).

The normal lens in a human eye, situated behind the cornea, is a transparent tissue. It contains 35\% (by weight) protein and $65 \%$ (by weight) water. Aging, disease (e.g., diabetes), smoking, dehydration, malnutrition, and exposure to UV and ionizing radiation can cause agglomeration of the lens proteins. Protein aggregation can take place anywhere in the lens causing lens opacity. The aggregation and opacification could produce nuclear (central portion of the lens) or cortical (peripheral) cataracts. Nuclear and posterior sub-capsular (the membrane capsule surrounds the whole lens) cataracts, being on the visual optical axis of the eye, cause visual impairment, which can finally lead to blindness. The lens proteins, in their native state, are small in size. As cataract develops this size grows from a few nm (transparent) to several microns (cloudy). Ansari and Datiles have shown that DLS can detect cataracts at least two-three orders of magnitude earlier non-invasively and quantitatively than the best imaging (Scheimpflug) techniques in clinical use today (Ansari, 2000, 1999).

\section{EXPERIMENTAL PROCEDURE}

The experimental set up is shown in Figure 1. Its main components consist of a DLS compact fiber optic probe, a lap-top computer containing a digital correlator card, and a solid-state laser/photo-detector box. The probe is mounted on an optical assembly connected through motorized actuators controlled by the computer to access and direct the probe to a desired location in the eye. The probe design and its application in 3-D scanning of small animals is described in detail elsewhere (Ansari, 1999, 1997). Thus it will not be repeated here. 


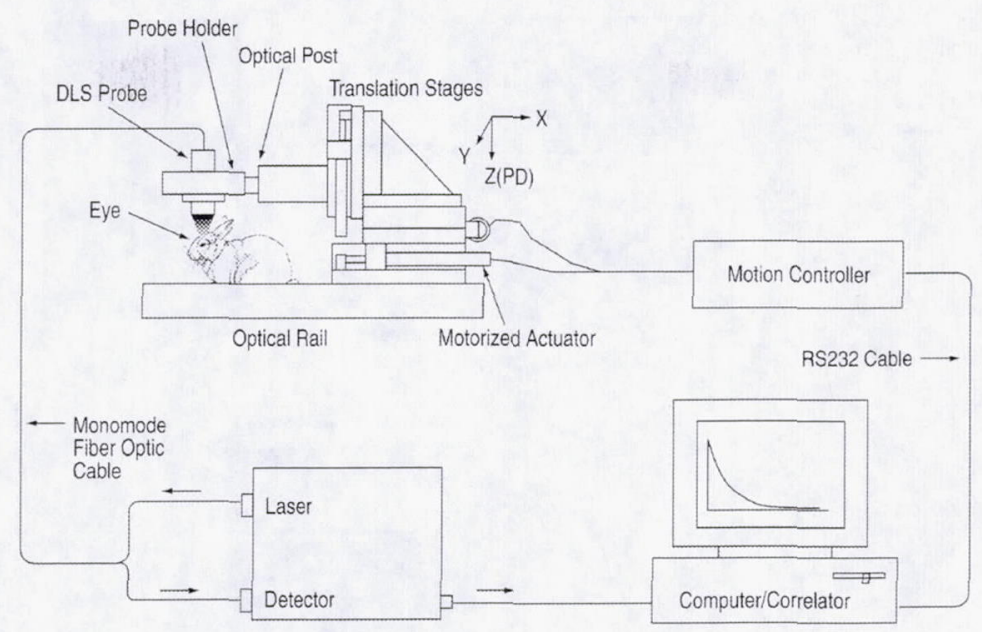

FIGURE 1. In-Vivo Animal Monitoring Experimental Set Up.

Four (5 week old) rabbits were used in this preliminary study. One animal was used as a control and three were exposed to X-ray (one time only) at a radiation level of $2000 \mathrm{rad}$ for 15 minutes. This high dose was used to accelerate the aging process since the effects of space travel on the body resemble some of the conditions of aging (White, 1998). The animals were anesthetized with an injection of xylazine ( $30 \mathrm{mg} / \mathrm{Kg}$ ) and ketamine $(7 \mathrm{mg} / \mathrm{Kg})$. Their eyes were dilated using a $0.5 \%$ solution of tropicamide. A laser power of 50 microwatts at a wavelength of $638 \mathrm{~nm}$ was used. The laser power is much safer compared to ANSI guidelines. Each TCF was collected for 5 seconds. The experiments were conducted at Oakland University under the NIH guidelines on handling and safety of animals. The X-ray animal model is described in detail by Matsuda (1981).

\section{DLS AND BIO-INFORMATICS: COLLECTION OF IN VIVO CATARACT DATA IN CYBER-SPACE}

One important aspect of monitoring an astronaut's ocular health is the ability to collect data non-invasively, frequently, easily and quickly, and to send it to Earth for examination by expert ophthalmologists in real-time. With reference to Mars, the "real-time" will certainly have some communication time lag from a few minutes to several minutes. Here on Earth, however, it would be easy to monitor human health, without this time delay, in remote and underserved areas of the world (e.g., Polynesia, Africa, etc.) and for defense personnel (naval ships, army battalions) at remote combat locations. The speed will certainly depend upon the internet traffic. As shown in Figure 2, we are setting up a system in cyber-space to conduct DLS/cataract evaluation measurements. The system has two components. First, a digital camera, microphone/speaker, a fiber-optic probe equipped with actuators, detector, and a digital correlator are located at the testing site (an animal facility in this case). The output of the digital correlator and the camera is connected to an internet site via the telephone lines. The second component consists of an operator at a desktop at another location (NASA GRC in this case) controlling the experiment and collecting data. The functional keys on the computer keypad are used to direct the fiber-optic probe at a desired location in the animal eye to collect data in 5 seconds. 


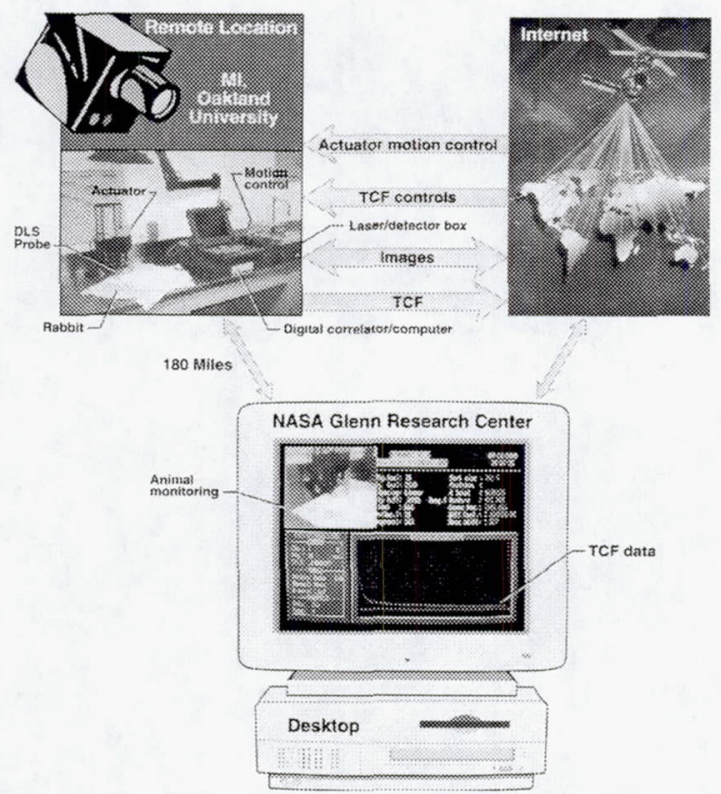

FIGURE 2 . Bio-Informatics System Currently Under Development.

DLS data was collected from the cornea, aqueous humor, lens, and the vitreous humor of the animal's eye every $0.5 \mathrm{~mm}$ after entering the cornea. In this paper we only present data from the nuclear region of the lens $(3 \pm 0.5 \mathrm{~mm}$ from the cornea). The DLS experiments were concluded on day 54 after the irradiation. The relative change in the average protein crystallin size is plotted for one normal and one irradiated animal (see Figure 3). Figure 3 is obtained by dividing each measured particle size, using the cumulant analysis method (see Stock, 1985), by the mean value calculated from the average of all the values in the control or non-irradiated animal from day $1-54$. The size remains constant (within 10 to $15 \%$ ) in the lens of the control animal (no radiation exposure). However, a significant increase in size can be noted in the experimental (irradiated) animal lens. Between day 1 and day 17 the protein aggregation seems to occur linearly. After a period of 2 to 2.5 weeks, the size increases almost exponentially. The average protein size in the lens of the animal exposed to ionizing X-ray radiation, compared with the control animal, increases by a factor of 2 by day 19, more than factor of 3 by day 31 , more than factor of 4 on day 40 , and almost by a factor of 7 by day 54 . An ophthalmologist (Dr. L.-R. Lin of Oakland University) examined the lenses of the animals using a slit-lamp biomicroscope at every time prior period to collecting DLS data. Slitlamp imaging did not show any evidence of nuclear opacity until day 60. Although posterior subcapsular cataracts, typical for the X-ray model (Sasaki, 1998), were visible from day 4 after X-ray, all the lenses were found to be transparent in the nuclear region up until day 60.

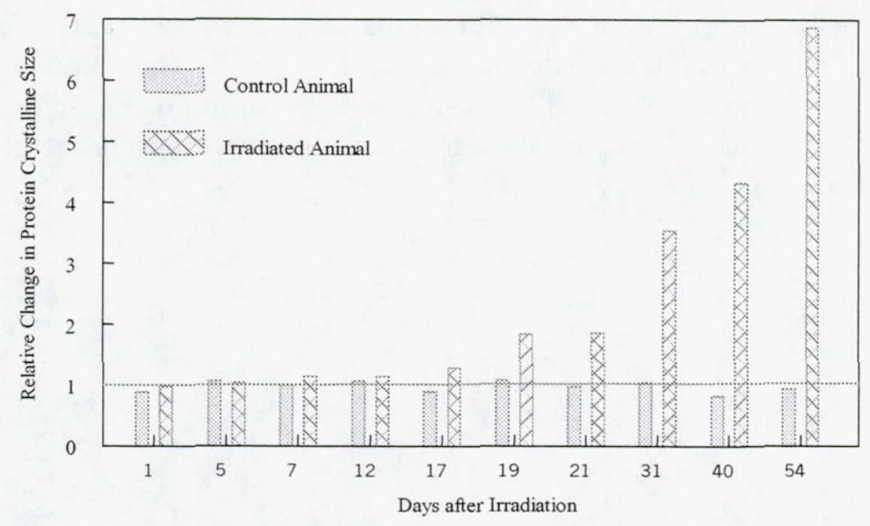

FIGURE 3. Environmental Ocular Toxicity: Effects of X-Ray Irradiation. 
On day 63, after X-ray based on the extent of lens swelling and complete opacity observed with the slit-lamp apparatus, all the lenses were found to have developed mature X-ray cataract (Sasaki, 1998) in the experimental animals. These results corroborate with earlier measurements on the diffusivity of protein crystallins in X-irradiated rabbits. (Nishio, 1984). We can examine detailed structural changes in lens proteins by looking at their size distributions obtained from the data analysis technique known as exponential sampling (Stock, 1985). In Figure 4, a set of size distributions for the lens nucleus of the control animal is shown for day 1 and for day 40 . As expected, the two size distributions are almost identical. In Figure 5, the size distribution for the lens nucleus of the irradiated animal on day 40 is significantly shifted to much higher sizes compared to day 1 after the irradiation indicating serious pre-cataract development, even though the lens nucleus has remained transparent as indicated by Slit-Lamp analysis.

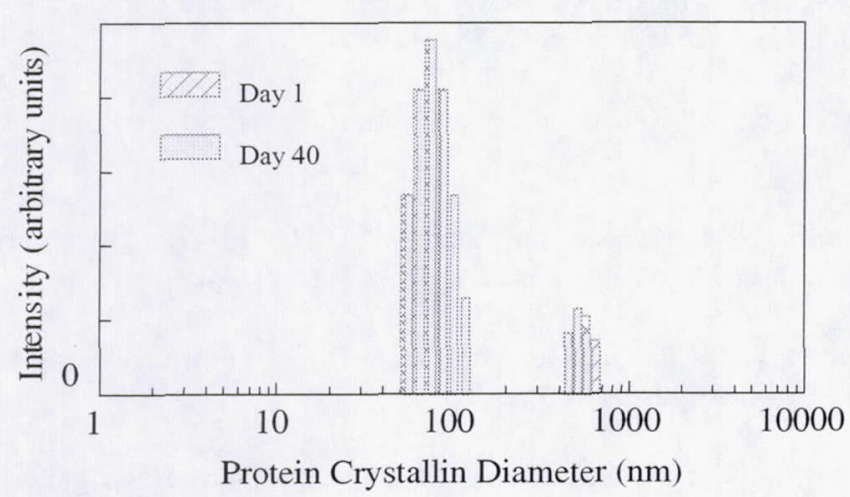

FIGURE 4. Lens Nuclear Protein Size Distribution in a Control Animal (No Radiation Exposure).

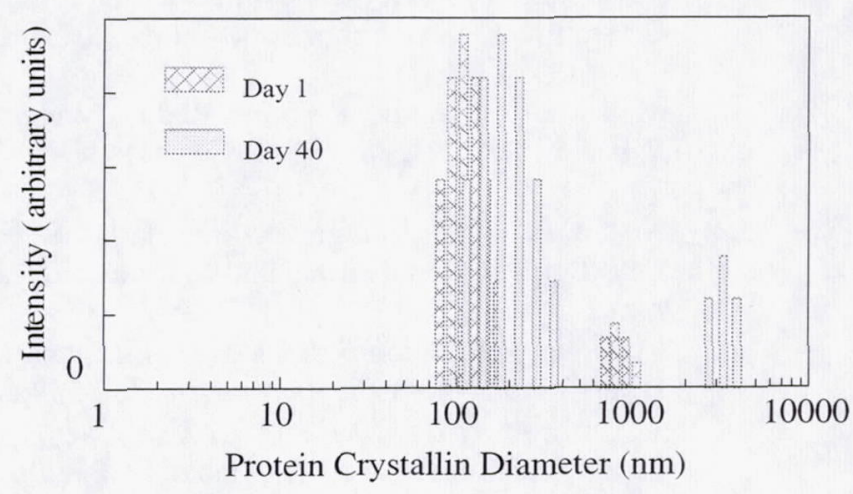

FIGURE 5. Lens Nuclear Protein Size Distribution in a Control Animal (X-Ray Irradiated).

\section{CONCLUSIONS}

DLS can detect radiation cataract much earlier non-invasively and quantitatively. Our approach provides good reproducibility and single end point measurements in terms of lens protein crystallin size. We see changes in the lens nucleus as early as one week after the radiation exposure. However, the traditional lens opacity evaluation methods still show the lens nucleus to be transparent until day 60 after X-ray irradiation. The DLS method would be very useful to monitor early damage to ocular tissues in a space environment so that counter measures could be taken. It can be a useful tool for guaranteeing astronauts'/cosmonauts' safety on-board the ISS, in-transit to and from Mars, and during its exploration. A DLS-bio-informatics system presently under development has the potential of providing on-line monitoring of an astronaut's ocular health non-invasively, quantitatively, and remotely. This may perhaps be the beginning of a new era of "celestial tele-ophthalmology".

\section{REFERENCES}

Ansari, R.R., Suh,, K.I., Arabshai, A., Wilson, W., Bray, T.L., and DeLucas, L.J., "A Fiber Optic Probe for Monitoring Protein Aggregation, Nucleation, and Crystallization," J. Crystal Growth, 168, 216-226, (1996).

Ansari, R.R., and Suh, K.I., "New Generation Laser Light Scattering Probes: Particles Size Measurements in Transparent and Turbid Media and Medical Applications," JASMA (J. Jap. Soc. of Microgravity Applications), vol. 15, supplement II, pp. 186-193, (1998).

Ansari, R.R., Datiles, M.B. III, and King, J.F., "A New Instrument for the Early Detection of Cataract Using Dynamic Light Scattering and Corneal Topography," Proc. SPIE, vol. 3908, no. 11, (2000). 
Ansari, R.R., and Datiles, M.B. III, "Use of Dynamic Light Scattering and Scheimpflug Imaging for the Early Detection of Cataracts, "J. Diabetes Technology \& Therapeutics, vol.1, Number 2, pp. 159-168, June (1999).

Ansari, R.R., and Suh, K.I., US Patent \# 5973779, “Fiber Optic Imaging Probe,” October 26 (1999).

Ansari, R.R., Suh, K.I., Tumminia, S.J., Russell, P., and Zigler, J.S., "In-Vivo Cataractograms Using a Compact Backscatter Dynamic Light Scattering Probe," in Proceedings of Medical Applications of Lasers in Dermatology, Ophthalmology, Dentistry, and Endoscopy, SPIE vol. 3192, pp. 202-210, September (1997).

Chu, B., Dynamic Light Scattering, Academic Press 1974.

Fedorenko, B.S., Abrosimova, A.N., and Smirnova, O.A., "The Effect of High-Energy Accelerated Particles on the Crystalline Lens of Laboratory Animals," Phys. Part. Nucl. 26 (5), pp. 573-583, (1995).

Matsuda, H., Giblin, F.J., and Reddy, V.N., "The Effect of X-Irradiation on Cation Transport in Rabbit Lens," Exp. Eye. Res., 33, pp. 253-265, (1981).

Nishio, I., Weiss, J.F., Tanaka, T., Clark, J.I., Giblin, F.J., Reddy, V.N., and Benedek, G.B., "In Vivo Observation of Lens Diffusivity in Normal and X-Irradiated Rabbit Lenses," Exp. Eye Res., 39, pp. 61-68 (1984).

Rutledge, R.E., Gibore, B., Martin, E.L., and Bildsten, L., "Chandra Detection of an X-Ray Flare from the Brown Dwarf LP 944-20," The Astrophysical J., 538:L141-L144, August (2000).

Sasaki, H., Lin, L.-R., Yokoyama, T., Sevilla, M.D., Reddy, V., and Giblin, F.J., "Tempol Protects Against Lens DNA Strand Breaks and Cataract in the X-Rayed Rabbit," Invest. Op. Vis. Sci., 39, pp. 544-552, (1998).

Sebag, J.,_Ansari, R.R., Dunker, S., and Suh, K.I., "Dynamic Light Scattering of Diabetic Vitreopathy,” J. Diabetes Technology \& Therapeutics, vol.1, Number 2, pp. 169-176, June (1999).

Stock, R.H., and Ray, W.H., "Interpretation of Photon Correlation Data: A comparison of Analysis Methods," J. Polym. Sci., Polymer Physics Edition, 23, 1393-1147, (1985).

Tanaka T., and Benedek, G.B., "Observation of Protein Diffusivity in Intact Human and Bovine Lenses with Application to Cataract," Invest. Ophthalmol., 14, pp. 449, (1975).

White, R.J., "Weightlessness and the Human Body," Scientific American, September 1998. 
Public reporting burden for this collection of information is estimated to average 1 hour per response, including the time for reviewing instructions, searching existing data sources, gathering and maintaining the data needed, and completing and reviewing the collection of information. Send comments regarding this burden estimate or any other aspect of this gertion Davis Highway, Suite 1204, Arlington, VA 22202-4302, and to the Office of Management and Budget, Paperwork Reduction Project (0704-0188), Washington, DC 20503.

\begin{tabular}{|l|l|l|}
\hline 1. AGENCY USE ONLY (Leave blank) & $\begin{array}{r}\text { 2. REPORT DATE } \\
\text { January } 2002\end{array}$ & $\begin{array}{r}\text { 3. REPORT TYPE AND DATES COVERED } \\
\text { Final Contractor Report }\end{array}$ \\
\hline
\end{tabular}

\section{TITLE AND SUBTITLE}

Non-Invasive, Quantitative, and Remote Detection of Early Radiation Cataracts

for Applications in Bio-Astronautics and Bio-Informatics

\section{6. $\operatorname{AUTHOR}(\mathrm{S})$}

Rafat R. Ansari, Frank J. Giblin, and James F. King

\section{FUNDING NUMBERS}

$$
\begin{aligned}
& \text { WU-101-51-00-00 } \\
& \text { NCC3-544 }
\end{aligned}
$$

\section{PERFORMING ORGANIZATION} REPORT NUMBER

National Center for Microgravity Research

21000 Brookpark Road

E-12549

Cleveland, Ohio 44135

\section{SPONSORING/MONITORING AGENCY NAME(S) AND ADDRESS(ES)}

National Aeronautics and Space Administration

Washington, DC 20546-0001 AGENCY REPORT NUMBER

NASA CR-2002-210591

\section{SUPPLEMENTARY NOTES}

Prepared for the Space Technology and Applications International Forum sponsored by the American Institute of Physics, Albuquerque, New Mexico, February 11-14, 2001. Rafat R. Ansari, National Center for Microgravity Research, 21000 Brookpark Road, Cleveland, Ohio 44135 (presently with NASA Glenn Research Center); Frank J. Giblin, Eye Research Institute, Oakland University, Rochester, Michigan 48309; and James F. King, Dynacs Engineering Company, Inc., 2001 Aerospace Parkway, Brook Park, Ohio 44142.

Project Manager, B. Singh, Microgravity Science Division, NASA Glenn Research Center, organization code 6712, 216-433-5396.

12a. DISTRIBUTION/AVAILABILITY STATEMENT

12b. DISTRIBUTION CODE

Unclassified - Unlimited

Subject Categories: 51, 55, 88, and 93

Distribution: Nonstandard

Available electronically at http://gltrs.grc.nasa.gov/GLTRS

This publication is available from the NASA Center for AeroSpace Information, 301-621-0390.

13. ABSTRACT (Maximum 200 words)

Human exploration of Mars may be a possibility in the next twenty years. Maintaining good vision is an essential aspect of achieving a successful mission. Continuous radiation exposure is a risk factor for radiation-induced cataracts in astronauts. A compact device based on the technique of dynamic light scattering (DLS) is designed for monitoring an astronaut's ocular health during long-duration space travel. Preliminary data on the simulated effects of ionizing radiation exposure to the ocular tissues of nonhuman animals and results on the sensitivity of DLS over established clinical procedures in investigating cataracts are presented. This capability of early diagnosis, unmatched by any other clinical technique in use today, may enable prompt initiation of preventive/curative therapy. An internet web based system integrating photon correlation data and controlling the hardware to monitor cataract development in vivo at a remote site in real time (teleophthalmology) is currently being developed. Cataract studies on-board the International Space Station (ISS) will be helpful in designing better protective radiation shields for future space vehicles and space suits.

\section{SUBJECT TERMS}

Radiation; Cataracts; Eye disease; Protein; Eye; Exposure; Ocular

5. NUMBER OF PAGES

12 16. PRICE CODE

\begin{tabular}{l|c|c|}
$\begin{array}{c}\text { 17. SECURITY CLASSIFICATION } \\
\text { OF REPORT } \\
\text { Unclassified }\end{array}$ & $\begin{array}{c}\text { 18. SECURITY CLASSIFICATION } \\
\text { OF THIS PAGE } \\
\text { Unclassified }\end{array}$ & $\begin{array}{c}\text { 19. SECURITY CLASSIFICATION } \\
\text { OF ABSTRACT } \\
\text { Unclassified }\end{array}$ \\
\hline
\end{tabular}

NSN 7540-01-280-5500
Standard Form 298 (Rev. 2-89)

Prescribed by ANSI Std. Z39-18 298-102 